\title{
TRANSLATING CULTURAL INTERTEXTUALITY IN CHILDREN'S LITERATURE
}

\author{
Isabel Pascua Febles \\ Universidad de Las Palmas de Gran Canaria
}

ABSTRACT

In the present work based on the concept of "cultural intertextualty" (Pascua, Adaptación), I will concentrate on the translation of some cultural markers which are signs of identity of a particular culture. After a brief summary on the different tendencies on translating for children during the last decades, I will show some examples from different stories. On the one hand, from tales deeply rooted in the British culture such as Alice in Wonderland, and on the other hand from other tales from part of the multicultural landscape of Canadian children's literature, where the multicultural aspect is particularly what gives the Canadian identity. Finally, I will present a new social project: translating multicultural children's literature for a new multicultural society.

KEY WORDS: Cultural intertextuality, children's literature, multiculturalism, intercultural translation, cultural markers.

\section{RESUMEN}

En el presente trabajo, basado en el concepto de "intertextualidad cultural” (Pascua, Adaptación), me concentraré en la traducción de algunas referencias culturales que son signos de identidad de una cultura concreta. Tras una breve exposición de las tendencias traductológicas más importantes del campo de la literatura infantil durante las últimas décadas, se mostrarán ejemplos de diversos cuentos. En primer lugar, de historias fuertemente arraigadas en la cultura británica, como es el caso de Alice in Wonderland; luego tomamos ejemplos de otros cuentos de la realidad multicultural que es la literatura infantil canadiense, donde ese aspecto multicultural es lo que refleja la identidad canadiense. Finalmente, presentaremos un nuevo proyecto social: traducir literatura infantil multicultural para una nueva sociedad plural e intercultural.

PALABRAS CLAVE: intertextualidad cultural, literatura infantil, multiculturalismo, traducción intercultural, referencias culturales.

\section{INTRODUCTION}

Despite the fact that the following paper has been encompassed in the volume titled Contemporary Problematics in Translation Studies, we should not over- 
look the evolution of the role which translation has played in the specific field we have before us today, due to the fact that, just as in any communicative activity, our paper has not materialized out of the blue. On the contrary, it arises from a specific cultural, historical environment, in the framework of a cultural polysystem which not only relies upon generic characteristics, but also upon the rules of verbal and non-verbal behaviour in each historical era, as well as the evolution and evaluation of the concepts of translation.

Although our ultimate objective is to illustrate resolutions for certain cultural references in the translation of literary texts for children, a somewhat superficial analysis of the evolution of this genre within the global panorama of literary translation can hardly be eluded.

Whatever the phenomenon, they can be analysed from different perspectives according to the aims for which have been proposed. Nevertheless, the translator's task depends very much on numerous factors, both objective and subjective, and which are in constant interaction. This means the topic must be studied from a historical viewpoint as well as generically, culturally and conventionally, especially when taking into consideration the fact that the stories are found among texts of traditional structure for each and every culture in their own rite.

From the moment that the theory of translation was integrated into the field of communication sciences, the concept of translation as an activity has undergone radical evolution. There no longer seems to be any discrepancy as far as the intercultural character of this activity is concerned. There is no uncertainty either when determining any communication activity as one of inter-subjectivity and, at the same time, as a social activity, since each communicator belongs to a society or culture with its own traditions, values, beliefs of all sorts, its rules for verbal and non-verbal behaviour in specific circumstances and so on; in other words, all the factors which make up what is usually referred to as the cultural polysystem. This does not mean to say that this is referring to a static concept; it is in fact subject to historical and social changes which go towards attributing dynamism. This dynamism also leads to one of the most marked traits of this cultural polysystem which is the language itself in its multiple functions and manifests, and in texts themselves, refers to what can be denominated as textual conventions.

What we have seen up until now does not, in today's terms, leave any room for discussion amongst the different schools of translation; however, a number of aspects have been approached from different angles in different schools and lines of thought. Above all, we are referring to the way certain cultural markers have been dealt with in both the past and present, these being signs of identity in a given culture.

In our research, we will be taking into account the fact that if each text is the result of subjective, intellectual and cultural activity, where there are no rules other than those for verbal and non-verbal behaviour in a socially relevant communicative situation and, on par, are historically conditioned, only then will it be possible to find a considerable number of translations of an original version at any one time. Hence, we can immediately rule out the idea of a unique, exclusive correlation between an original text and its translation. On the contrary, this affinity possesses a dynamic, functional and relational character. 


\section{DIFFERENT APPROACHES TO TRANSLATING FOR CHILDREN SOURCE-TEXT ORIENTED TRANSLATION}

It is hardly surprising, given the tradition in studies on juvenile and children's literature, that the first countries which showed any interest in translations of this genre were the Nordic nations, followed by Germany and Great Britain. A special mention has to be made of the Swedish author, G. Klingberg, organizer in 1978 of the International Research Society of Children's Literature symposium which focused its attention on the translation of infant and children's literature. In one of his publications (1986), the author deals with the affinities and differences between translation and adaptation in children's literature, in which he assumes, in principle, that any adaptation is a show of disrespect towards the children they were written for, and that the only worthy version is the translation true to the original story itself. According to Klingberg, any piece of work written for children has a "degree of adaptation" created by the author of the original, something which should be retained in the target text (TT), and thus respecting the fidelity of the source text (ST).

What is more, Klingberg also considers a number of concepts as fundamental: the cultural context adaptation (where cultural features should be explained to the readers in order to understand any foreign information); modernisation (where adjustments are made to the time span so that it is closer to the reader); and purification (modifications made only if they are in correspondence with the current values of the target culture.) The author, regardless to say, is strongly against any type of modernisation.

Although we agree with certain aspects of his research, its scope is somewhat limited, concentrating on isolated words and text-segments. He focuses more on the micro-level than on the macro-level in a translated text.

\section{TARGET-ORIENTED TRANSLATION}

Translation studies radically changed throughout the 1980's with the introduction of the polysystem theory. Although the most important pioneers of this line of thinking were Even-Zohar and Toury, it would be Zohar Shavit, a scholar at the same university, who put the theory of the polysystem into practice by using it in children's literature and its corresponding translations.

Shavit claims that literature written for children does form part of the literary polysystem and occupies a peripheral position. It is precisely this so-called inferior status that allows the children's author or translator the possibility of "manipulating" the text. Zohar Shavit establishes this manipulation according to two principles:

1. The adaptation of the argument, language and structure to the children's reading skills and level of comprehension.

2. Given the didactic role which all children's literature plays, modifications to the text will be made possible to the point where it is suitable and useful for the child, according to what society decides as "good for the child." (113) 
As far as criticism of Shavit's stance is concerned, there is no doubt that the TT can be changed, enlarged or reduced, in other words, "manipulated," but there should be certain differences in the changes made concerning the translation. When translating for children, all the "manipulations" must safeguard acceptability in the target culture; however, from our point of view, the limits imposed by Shavit have no connection with communication activities, but appear to be merely ideological: "What society regards as educationally good for the child." This doesn't mean to say that translations ignore the ideological factor, nevertheless, its presence is somewhat limited owing to the reasons we have just seen. We do, however, agree with the fact that the acceptability in children's literature (as opposed to "adequacy") is linked to the children's individual characteristics, underdeveloped reading skills and their limited experience in life, which overall, makes it quite difficult to cope with strange situations which we would usually expect to find in literature for adults. Subsequently, the needs and expectations of young readers, in other words, the "acceptability," are more important; they hold, according to the authors of the polysystem theory, supremacy over fidelity towards the ST.

\section{FUNCTIONAL PERSPECTIVE}

Amongst the pioneers of theory in German spheres, it was researchers Katherine Reiss and Christiane Nord who concentrated on children's literature. As we know, supporters of this trend defend the theory that the translator's strategies and options (translational procedures) rely on the communicative function which is given to the TT in the target culture, and all equivalents are rejected. From our point of view, Christiane Nord wasn't quite as radical when she introduced the term "loyalty." Here this designation refers to not only the respect for the author of the original text, but also for the client who has ordered the translation, together with the readers in the target culture. It is here, we feel, that there lies the great innovation regarding functionality. At last, there was a line of thought that started talking about the child-reader, and moreover, about the translator as a cultural mediator, someone who is familiar with two worlds - the bilingual and bicultural translator.

We believe Katherina Reiss is right when she mentions that the problems found in translations of children's literature are no different from those found in literature for adults; however, they have to be resolved along different lines for several reasons. Firstly, the translator is an adult who has to be able to master the language written for and spoken by children; secondly, children's literature is really translated for two types of receptors: the child on the one hand, and the adult who buys, recommends or reads the book, on the other; lastly, this genre is translated for a collective group whose linguistic expertise and general knowledge are still not fully mature and therefore require specific adaptations which will always depend on the function attributed to each translation in particular.

Consequently, from now on, the translator will not only be asked to take the linguistic, situational and cultural contexts into account, but he will also have to consider the type of text and text conventions. Which of these factors will be 
decisive at the time of adaptation will depend on the competence of the translator. The translator is in fact the author of the new target text and is required to make decisions in areas of acceptability for young novice readers in a new culture which the author of the original text simply wouldn't have conceived.

\section{THE DIALOGIC SITUATION}

To this hypothesis, put forward by the authors we have just mentioned, based on the function a specific literary text fulfils, on the one hand, and the importance of the role of the child-reader, on the other, the Finnish researcher Riitta Oittinen adds the concept of dialogism (Bahktin). Currently speaking and without any question at all, it is this specialist who has carried out the most rigorous study on translation of children's literary texts; studies which have had an influence not only on later research, but on those researchers dedicated to this field of study as well.

Her main principles of translations are the following (Translating 161-168):

1. Translation is a collaborative and dialogic process which creates texts for different purposes, readers and situations. When translating for children, different authors (the author and the translator-author), different readers (source readers, the translator as a reader and target readers) and different illustrations come together, and so new meanings emerge.

2. Another principle is considering translating for children as a "cannibalistic action: a continuous ritual of crowning and uncrowning. Translation is a never-ending, unfinished process." She considers that on translating dialogically, translators are faithful to the texts, the author, the child-reader and finally within themselves.

3. Oittinen does not agree with Klingberg's difference between adaptation and translation. We agree with her on considering "adaptation and translation part from the same whole: all translation includes adaptation." Actually, we always think of our future readers, who she calls superaddressees.

4. However, her most important contribution to the field of translating for children has been the importance she considers the illustrations to have in a specific dialogic situation. In her recent works ("Where"; "Translating") she has deeply studied the relationship between the illustrations and the text (specially translating picture books or films) in the modern world, so influenced by the visual.

There is no doubt whatsoever that the visual message has an influence on the verbal traits and vice-versa; the characters and plot are enhanced by the illustrations. Oittinen herself, who translates and illustrates stories, comments that when she is translating, she perceives that the illustrations "tell" her a great deal about the different personalities.

Finally, we would agree with the author when she states that "When reading and writing, authoring or illustrating, the translator is in a dialogic interaction 
with all children [...] a thought, a sentence, a text, a picture, they are all involved in a never-ending dialogue." (Translating 168)

\section{PRESENT TRENDS IN TRANSLATING CULTURAL INTERTEXTUALITY FOR CHILDREN}

After this somewhat modest insight into the translation of texts for children and on seeing the place it holds within the general panorama of literary translation up until the beginning of the 1990s, we shall now concentrate on our own research and the experience we have mustered.

Although, at first sight, it may seem that translating for children or for adults poses the same problems, it should be remembered there are some special properties. Despite the fact that some view children's literature as a field apart from adult literature, we believe that this bearing is detrimental and undermines the discipline of written stories for infants. Of course, there is a different set of linguistic characteristics and, above all, a unique kind of reader; nevertheless, they cannot be classified separately as two different types of literature. As Enzo Petrini states:

The widely used denomination children's literature has taken on a restricted meaning - even contemptuous - due to the continual and more frequent emphasis on "children's" rather than on the latter term "literature." (qtd. Valvivieso 9)

On centring our attention on the translation of children's texts, a number of fundamental elements should be considered closely: on the one hand, the focal point must, beyond any doubt, be the child as the reader; and on the other, there is the acceptability, meaning that the TT reads naturally and that it contains the characteristics we would expect of a tale written in the target language. We shall endeavour to explain these ideas more accurately.

If the first factor to bear in mind is that we are translating for children, does this mean the text should be translated hastily, without paying much attention to the vocabulary or resorting to endearing lexicon, as is the case on so many occasions, simply because the child is so young and consequently fails to understand? Absolutely not - translating for children is the same as writing for them- as Anatole France once said and quoted by P. Hunt: "When you write for children, do not adopt a style for the occasion. Think your best and write your best" (49).

What's more, if we bear in mind the fact that communication has to exist in any type of translation, that very communication needs special thought, not imposed by the adult, but by the limited tools of understanding and experience which these particular readers possess - a topic which will be dealt with further on. The type of language chosen should be shared between both adult and infantile levels; the sort of language which is able to make sense, without any need to be limited or made babyish; on the contrary, it should be stimulating and help the child-reader to progress. There are a great many expert translators of children's literature who are convinced that the only way to achieve their goal is by entering 
into the infantile world, and although inevitably we all grow up at some stage or another, we have to try to pick up and retrieve that childish streak in us, which we all have hidden somewhere, deep down inside.

Another important point to remember is that, when reading the story, the result should sound natural, plausible and fluent. As far as syntactical or lexical structures are concerned, the child should never be able to think that what he is reading comes from a foreign text. A story translated into Spanish, the language we speak, should always follow the textual conventions of the target language; however, any linguistic or semantic elements influenced by any foreign sociocultural context will require adaptations, clarifications or explanations. It is also true that opinions are divided when discussing these translation techniques, but then again, everything will depend on the function of each translation in particular.

One of the difficulties that acceptability and naturalism pose is the socalled reader duality, the bipolarity that exists when reading literature for children. Of course, there is really only indirect translation when it comes to children's literature; nonetheless, we must have not only the child-reader in mind, but also the parents who buy the book, the teachers or librarians who recommend it, their didactic roles, the publishers and their standards, even the censorship, and so on. Therefore, infantile literature and translating for children is the result of a combination of different systems within a culture: social, educational and literary.

Now that some light has been thrown on these more generic issues, we can go on to consider some of the modern-day tendencies in translating literature for children which, quite naturally, is closely related with those of literary translation itself.

In any translation, as we have already underlined on several different occasions, a dialogue is established between author and translator; subsequently, it is important to know and to recognize the role of the latter. We have already postulated in earlier papers that, above all in the translation of fiction, the translator - who is acting as mediator between languages and cultures - has to go through the same creative procedures as the original author experienced at the time of creating his composition. This creative process was very much forgotten for some considerable time, but we are of the opinion that translation is bound by, not only the subjective nuances of the author on creating his piece of work, but also by the subjective nuances which the reader-translator finds when he or she is translating during the subsequent creative procedure.

Although we have no doubts about certain strategies and translation theories applicable to literary translation, translations of literary texts for children cannot answer only to theoretical-practical hypothesis in the more generalised field of literary translation. In the case of children's literature, it is fundamental that a much deeper look be taken into the nature of the genre, the place these texts occupy in their own particular culture and determining the universal set of values which have helped them become part of the national and international patrimony. For this very reason, we would have to follow the guidelines laid out in modern day infant and children's literature. Following these proposals would appear to be quite apparent if we coincide with Hermans when he claims translation to be "a transaction 
taking place in a communicative, sociocultural context" (26). We are aware of the fact that in each and every social context there are a series of rules, restrictions and regulations imposed by authorities or individuals who play a part in the translation process and which condition it to one level or another. Translation does not develop on its own accord or in isolated situations; everything depends on not only the conditions and terms that encompass it, the conditions in which a text is created, but also on the impediments it may find. One thing is certain: the translator finds himself in a position which is critical of publishers, institutions, social and ideological practices which change with both time and place.

In earlier studies, we also presented what we have come to understand as translation and adaptation (Pascua, Adaptación), the concepts of acceptability, and the visibility and intervention of the translator (Pascua, Mundos). On this occasion, however, and based on our concept of "cultural intertextuality" (Adaptación) we will concentrate on the translation of cultural markers, which are the signs of identity in a particular culture.

As previously stated, translators cannot hide behind the author; they must take part in the dialogue, intervene and change the text and, in a favourable sense, "manipulate" it. But all the changes translators make for the child-reader must be motivated by communicative reasons which we have called: "intertextual culture," in other words this is "the lack of knowledge of cultural presuppositions; no correlation as far as the rules of verbal and non-verbal behaviour are concerned, and lastly, no correlation concerning textual conventions." (Pascua, Adaptación 159)

On the other hand, the concepts of visibility and interventionism in translation have spurred great interest. In more recent debates and contemplations, translators have fought for a more relevant place, so that they have more say and that their rights are more steadfast. From our point of view, long gone are the days when the name of the translator failed to appear on a translation; nowadays, the translator's name is always published and even as the author of the translated edition. Deference to the original text, transparency of discourse or the invisibility of translated texts has become a thing of the past. It's about time that the voice of the translator were heard; that the figure of the translator were given a certain amount of flexibility and freedom to resort to strategies and adaptations which he or she considers appropriate, and which are very often inevitable and essential. In this way, the translation, the recreation of the original text that we mentioned previously, will achieve acceptability, one of the most important requisites when translating literary texts for children. Although these concepts may seem interestingly appealing from the point of view of translation and research, a problem inevitably arises when deciding up to what point the translator ought to act, how far he is able to go and where the borderline lies.

From as early as the 1980s, Javier Marías began asking himself where the limits of the "admissible" lay. In effect, there is good reason for there being a translation, it is based on the original, which gives it life but represses it at the same time. Many consider that the presence of the original text provides the intrinsic character of the translation, contrary to what Marías thinks, as he believes it is precisely the absence or omission of the original which characterizes the translation. The transla- 
tion already undergoes a transformation as it is passes from one language to another; it doesn't reproduce or copy, it unveils a unique experience in its own language for the first time; it creates what were merely thoughts and ideas held in the mind in another language into words in the target language; the original text therefore, in a translation context, plays no role at all.

As a result, we firmly believe the translator to be the author of his translation, the author of a new text in another language and, in the task which concerns us, for children from another culture. However, there is and has to be a limit, there has to be a balance, but as is always the case, the eternal controversy of the translator's "ethics and standards" arises. The limits and equilibrium concerning the translator (here, we quote Oittinen's research once again), will be enforced by the dialogue which ensues between the translator's inner self and that of the author of the original text; between the translator and the child-reader; between himself as a grown-up and the deep-rooted element of childhood he still possesses, together with all the experience he has gathered throughout life - as a child and as an adult - his own world, past and present, together with his knowledge from the world of reading. The translator can't pretend he doesn't exist, hide himself away and cast himself into self-destruction. The limits can also be found in the text as a whole and in that special sense and the experience which each translator amasses. We are very much aware that this is no easy task; nevertheless this is the challenge which faces each and every translator when confronted with a tale, a particular story, in a different specific communicative situation. Texts, according to África Vidal, are open to interpretation, but not to over-interpretation; when translating, subjectivity can't be avoided, but neither can it be forced upon the readers (120).

To illustrate some of the problems encountered in texts, the strategies followed to face them and the changes carried out, we will take some examples from some of our translations. Firstly, we shall take a look at some episodes from Carroll's Nursery Alice (Alicia para niños) (Pascua, Mundos). In the first example, we concentrated on what we called the lack of presupposed knowledge of the child:

In the title of the fourth chapter, "The Caucus Race," we observed an expression of North American origin which is used at the meetings of political party leaders when they have to decide who is to be their candidate for the following elections. Possibly, Carroll satirised and made fun of these well known meetings, where members discuss and think about several issues without making any decisions, but, of course, everyone wants to get something. In some translations we found "Carrera electoral" or "Carrera en comisión" for Caucus Race. Even in the first Spanish Alicia we found "Una carrera electoral que trae cola." We did not believe that any of these solutions were adequate enough, because they had no relation whatsoever to the chapter under that title. Keeping this in mind we opted for the title "Carrera en grupo" or even "disparatada, alocada, desordenada," quite different from the original, but that would make it acceptable in the new text and for new readers (Spanish children of today, between four and six years of age).

Like any other cultural reference, "food" normally poses problems in translation, as illustrated in the following example. In chapter six, some children are celebrating their dog's birthday and are trying to think of a present: 
ST: Now, what is it we like best of all, on our birthdays? And at last we called out together: "Why, its oatmeal-porridge, of course!" (Carroll 22)

In Spanish, "oatmeal-porridge" would be translated for "gachas de avena" and possibly during the author's time, children ate oatmeal-porridge at birthday parties, but today this wouldn't be acceptable. It would be rather strange for Spanish children to celebrate a birthday with "gachas de avena." As in the text it also mentions that this dish is eaten with a spoon, we therefore decided to translate it for "natillas de chocolate" (chocolate-flavoured custard), among several other possibilities.

TT: A ver, ¿qué es lo que más nos gusta de nuestros cumpleaños? Y volvimos a pensar y pensar. Finalmente, todos dijimos a la vez: ¡Claro, natillas de chocolate! (Pascua, Mundos 113)

In the following, we will illustrate an example in which we were creative, inventive and juggled with the language. In writing Alice, Carroll always sought the "acceptability" of his readers; this very much coincides with our strategy in translating stories for children. Didn't Carroll experiment with the English language? Subsequently, we can also experiment finding words in our own language as Carroll did with his. Carroll's world needs to be re-invented within our language, without doing away with any of his ideas.

In the episode with the Cheshire Cat, the author alternates between "smile" and "grin." He uses "smile" at the beginning of the chapter when it is a sweet smile, and "grin" for a mocking smile, almost arrogant, at the end and which surprisingly is written with a capital letter. In our translation, this drove us to choosing "sonrisa" for the first, and for the second, we opted for a new word. We came up with several variants: sonrisamueca, mueca como sonrisa, sonrisa con especie de mueca, amidst others, but we finally decided on Muecasonrisa, as we thought that it sounded better in Spanish and was more amusing for such a particular reader:

ST: Wasn't that a curious thing, a Grin without any Cat?... If you turn up the corner... (Carroll 36)

TT: ¿Verdad que es algo muy raro ver una Muecasonrisa sin Gato?... Si levantas la esquina de esta página,... (Pascua, Mundos 139)

In order to be coherent with all the points previously mentioned, as translators, we had to make decisions to produce a specific target text. It was assumed that the general tendencies in translating a certain text should be subject to specific strategic decisions: in favour of "foreignizing" or "domesticating" a text (using Venuti's terminology); in favour of following the social and educational norms of the source culture or focusing on the interests of the target child-reader; in favour of the literalism or the naturalism, credibility and acceptability of the new text, etc. However, in spite of the necessity of the global or general strategies, we assume that there must be a certain balance between general translation strategies and the options to solving the problems in a particular text. Thus, although translators should have a 
general strategy in mind, the different problems encountered in the course of a specific translation require and compel some negotiation to be made with the strategies adopted.

In the examples that have just been shown, with textual acceptability for child-readers as the objective, the general criterion used, according to the terminology used by Venuti, was "domestication," due to the fact that the main aim which we had intended for this translation - the predominating function- was that small children (besides the fact that they didn't know how to read), were able to enjoy, understand and accept the narrative action and its central characters. These examples have been shown to underline the role of the target reader which is so fundamentally important in translation. Our intention was not in this particular text to highlight a foreign culture or to broaden our readers' knowledge with specific cultural markers from Britain, for instance, the porridge oats (gachas de avena) in a birthday party.

\section{A NEW PROJECT: SOCIAL-MULTICULTURAL TRANSLATIONS}

Translations of children's texts, as we have just seen in the previous chapter, apart from being closely related to current translation tendencies, are inseparable from the historical-social time slot in which they are situated and also constitute the literature written for children at a specific point in time.

Children's texts, as they are currently known, and which we would prefer to rename as texts written for children implies a far more realistic bearing. They seem to be marginally masked in narrative fantasy, but this doesn't suggest they are any less credulous. What's more, we should always remember that these texts reflect the culture of an ethnic group in a precise period of time in history, subsequently, it is important that all those who come into contact or use these texts, such as authors, translators and teachers, amongst others, are familiar with the sociocultural realities, so that these stories are able to make sense to the child-reader and which will pave the way for new knowledge about the new life and goals they will be striving for.

Nowadays, the objectives of children's literature are not just didactic and even less so, a question of simply doing business — although in practice, this may be hard to avoid. Written texts aimed at young child-readers should be there for their absolute enjoyment; however, they should also serve to enhance their knowledge of the reality in which they find themselves. We are not trying to say that we believe children's literature to be the only formula for opening the minds of future generations, but we do consider it to be a very important activity, so much so, that it has and always will play a vital role in society and for its readers. Amongst the wide diversity of functions in children's literature, it is the didactic, informative and the social functions (besides ludic, creative and emotional functions), which are the most important as far as our research work is concerned. When resorting to the socialising function, the child-reader is helped to integrate into the society which he or she is trying to settle into. This brings Bravo-Villasante to mind when she 
states that at the time of wanting to transform society, there is no better way other than through literature (82). Quite rightly so; to be able to transform society, a start would have to be made by stirring the consciousness of the citizens of the future which, in other words, refers to the children of today.

There is absolutely no questioning the fact that today's society is characterised by the confluence of different ethnic groups with different cultures due to the influence of migratory tendencies. The withdrawal of all frontiers within modernday Europe has led to the fact that we now live in a cultural melting pot and whose peoples not only come from European countries, but also originate from other continents and culturally differ quite substantially -Africans, Asians, Arabians, to mention but just a few. On bringing this to light, there are a great many who ask themselves if we are sufficiently prepared for this great sociocultural changeover. Without having gone into any great depth on the subject or not being altogether familiar with the matter, will quite probably give rise to a number of differences or problems which can be debated, on bringing together a number of people from very diverse origins. Trying to avoid these very conflicts should in anybody's terms be an objective for all those involved in any sort of education or intercultural activity.

As an academic, translator and educator, we are eager to go into more depth concerning the study of children's literature and its translation. We have no doubt about the fact that our interest has not simply been motivated as a result of some personal commitment or concern. It should not appear strange at all that a translator finds interculturalism of great interest if one considers that translation is an act of intercultural communication. It is because of that very concern and interest that the idea for this project aimed at our environment arose, where young Spanish readers, by means of translated multicultural children's stories, can get to know other children with different cultures from other parts of the world and thus become multicultural readers themselves. In this way, we as adults could help to educate our children to tolerate and respect children who come from other places and join schools in our countries. All this implies preparing our future generations to become citizens of a new society in which they are able to "distinguish without segregating" (Pascua, "Multiculturalismo" 277).

One of the key issues in this social translation project is to divulge "multicultural" literature and, as translators and teachers of forthcoming translators, "multicultural and social translation" for a new group of recipients: those children who, although living in a specific country such as Spain, come from ethnic groups with different languages, customs and traditions.

Hence, since 2002, all of our work has been aimed at topics related to social translation, which, in other words, refers to the translation of literary texts written for multi-cultured children in order to develop an intercultural education (see bibliography).

Social translation and interpreting is a relatively new field in Spain and is always a topic for discussion, stirring interest whenever it comes up. Even if things at professional or research levels are just beginning to gain ground, this is not the case at all when it comes to countries traditionally acknowledged as migratory destinations since the 1970s and '80s, such as Canada, the United States, Sweden and 
Holland, amongst others. Nevertheless, it seems as if researchers are one step ahead of those responsible for the social needs in this field (educational criteria guidelines, publishing houses and so on.) In one of the numerous debates held during the II International Conference on Translation: Children's Literature and Didactics at the Universidad de Las Palmas de Gran Canaria in March 2005, with Dr. Amando López (Head of the Spanish Language and Literature Didactics Department at the Universidad de Murcia), it was suggested that although children's literature dealing with intercultural topics, written in Spanish, is very slowly on the increase, teachers and educators really required a wider selection of texts which they would be able to choose from. There is still a long way to go concerning the need for a number of texts which could help teaching professionals reach satisfactory levels regarding intercultural education. This, needless to say, doesn't happen in countries such as Canada or the United States (Pascua, "Inmigración"; "LIJ"), and it is in these countries where writers and translators each have the opportunity of contributing to this project on intercultural education.

We believe that this new reality can be approached in two ways. In the first place, in order to avoid breaking away from their own language and culture, the newcomers may participate in activities where children can read tales in different languages spoken in their original communities. Secondly, and at the same time, if we want to attain an intercultural education, the activities must be reciprocal. All the children belonging to the same community are aware of having something new in common: a new language that they share and use while learning more about the other children in their environment. All this can be achieved through the work of translations of these multicultural texts by means of translators as social mediators.

Today, scholars in translation studies seem to take a greater interest in communication and culture rather than linguistic issues as such. So, translation is seen as more of an action between cultures than simply just a language. Moreover, translators of children's literature are facing the new challenge of translating multicultural literature for children.

Up until the present day, students studying translation have been taught that as culture is the central issue in translating, they should be not only bilingual, but also bicultural. However, the situation gets even more complicated when working within multicultural literature written in a familiar language, but in unfamiliar surroundings, for example, stories written in English, reflecting diverse cultures from the North Pole, the Caribbean Islands, China, Palestine or Latin America. Does this new situation imply that only a translator from Asia can translate stories about Asia, and only an expert on African culture is able to translate an African tale? What then should translators do about the true-to-life multiethnic "mosaic" of written stories coming from all over the world? Should translators have to familiarise themselves with all the far-away cultures of original stories? For example, what should translators do with the stories by authors like Tololwa Mollel (from Africa), Luis Garay (from Nicaragua), Paul Yee (a Chinese-Canadian), Ricardo KeenDouglas (from the Caribbean Islands), Jan B. Waboose (a Native American), Robert Munsch (born in USA), Shihab Nye (from Palestine) or Rukhsana Khan (from Pakistan)? 
What kind of strategies should be called for when translating these tales written in English into Spanish? As our main task in those translations is to let our readers know more about the foreign world out there and how the "others" live, we would naturally opt for "foreignization," in other words, maintaining the exotic and the unknown in the translated text, contrary to what we set out to do in the Alice translation, as examples previously showed. Keeping intercultural education in mind, it is important for us to maintain the "cultural references" of the original text, and yet, the issues of acceptability and readability must be taken into consideration as well.

More attention should be paid to those cultural markers which take the Spanish readers into new worlds, and give them the opportunity to meet and respect other children from different parts of the world. Readers will be able to understand that what they have before them is a foreign text and they should be able to "feel" that they are reading a translation of the original, but only as far as the exotic names, places, food, clothes, customs, and so forth are concerned. Translating from this angle emphasises singularity, the essence of translating multicultural literature.

Miguel Sáenz expressed the need for new ways of translating in a multicultural environment. However, he points out that little does it matter if an image or metaphor is commonplace in Turkish or German or if it is included in the idiolect of a Turkish author who writes in German. Moreover, we believe that what is really important is that the image is there and must be effective in the target language. This is another of the key issues in this project: how to find a solution to new problems of this sort which translators are faced with when translating multicultural literature; what strategies are to be used if they differ from those applied to other bicultural texts?

The stories which we have chosen to show social translation are those which deal with issues like the problems resulting from the Diaspora, the authors' feelings about being a foreigner and leading an everyday life, such as playing in the park and going to school in an environment with several ethnic identities. This "inter or cross-cultural" literature suggests that there are cultural borders that need to be crossed. We have bridged numerous cultural borders on translating books such as:

\section{Mollet Tololwa. Big Boy. New York: Clarion, 1995.}

Mollet, a Tanzanian native now living in Canada published this book for young children. The author connects the past with the present, typically characteristic in his works, thus projecting realities of contemporary relevance using traditional African folklore. Although he has received many national and international prizes, his works still have not been translated into Spanish, consequently this is the reason why we have translated The Big Boy in class with some of our students. We have chosen him as he is a teacher, a spokesman for Africa, a writer and mainly because he acts as a cultural bridge.

In his books he tries to introduce children to a different view of Africa and tries to make tradition contemporary. This book, although based on a traditional folktale, wants to situate the protagonist in a modern setting with white sneakers, 
shorts and modern things around him at home, showing that Africa is not only made up of grass huts. He has written a story that is, as he says, a "mythical element in a realistic framework." It is about a boy who wants to be as big as his brother. During nap time, the boy is granted a wish by a folkloric, magical bird, the TunukiaZawadi, and in the story, his wish comes true. But, in fact, he actually becomes a giant which doesn't make life very easy for him. At the end of the story, he longs to be cared for by his mother and family because after all, he is only a little boy who awakens in the arms of his mother.

One interesting thing about our intercultural purpose and, at the same time, wanting to leave out the didactic function, present in every story for children, we included a short glossary explaining the terms and vocabulary used throughout the story in Kiswahilli. This will help Spanish pupils at school to get to know African culture better and to become more familiar with the boy and his surroundings.

\section{Robert Munsch. From Far Away. Toronto: Annick, 1995.}

In this story, we are able to appreciate another vision which differs from the previous one we have just seen. The main plot deals with topics such as war, the Diaspora, how necessary the exodus actually is, arriving in a new country and the culturalization which takes place. The story is narrated, however, in first person and from the lifelike perspective of a young girl, co-author of the tale, which adds a touch of realism and lucidity to a story full of appalling experiences. It gives an account in the first episodes of how the girl endured the suffering in war-stricken Beirut, to go on and describe the humiliation she had to go through in a new land, as a result of not being able to understand the customs of her class mates and teachers. The main character, Saoussan, lives in Beirut with her parents, but the war forces them to flee the country, and after a long and miserable journey to get to Canada, she finally arrives at a school where she feels lost and unprotected - this, of course, leads to some very unpleasant experiences. Nonetheless, the story is not written with a dramatic slant to it. It also mentions, although superficially, the conflict which arises between first and second generation immigrants when Saoussan wants to change her first name to Susan, a name which sounds more familiar, but her mother gets angry and, consequently, doesn't want to hear anything of it. In the end, however, our heroine overcomes all these obstacles and lands up being one of the most talented students in her class and lovingly remembers the days with her first teacher.

\section{Maxine Trottier. The Walking Stick. Toronto: Stoddart Kids, 1998.}

In this charmingly written story, our young hero, Van, comes across a walking staff under Buda's sacred tree. From then on, the young boy keeps it as his lucky charm; unfortunately, war breaks out soon after and he has to flee the country, together with his wife and baby daughter on a long journey to the New World. On his long and perilous quest, the walking staff becomes his biggest comfort, although at the same time, it would later come to serve him as a link with his past. In the new land, free from wars and persecution, his daughter, Lynn, grows up and marries a young man, quite different from her and her family: blond and pale-skinned, but 
with blue eyes which show how deeply he loves her. After a number of years, and with their odyssey of settling down in a new country well in the past, it is Van's granddaughter, with soft black hair and blue eyes, the one who returns to Vietnam to place Van's stick, the coveted lucky charm, under the sacred tree of Buda.

In all the stories, we encountered cultural markers concerning the names of people (Oli, Mbachu, Saoussan, Lynn, Van, etc.), a bird which grants wishes (Tunukiazawadi), trees (Kuyu), meals (ugali) and materials used in women's dresses (kanga). In all of them, we decided to leave these features in their original form (foreignization), as our intention was precisely one of proliferating these cultural references.

\section{CONCLUSION}

1. Those of us who decide to devote, in one way or another, all our professional lives to educating young children and juveniles, have the moral obligation of familiarising ourselves with the social circumstances which surround us. We can't ignore the fact that the first stages of growing up and education of any human being are the basis for the future generations to follow which, sooner or later, will become part of the social multicultural framework that happens to form part of our lives in the 21st century. As a result, we feel almost obliged to spend at least a part of our professional and personal endeavour to the education of the future citizens immerse in an intercultural world; trying to open their minds to other individuals, to different cultures, in different situations, and all this, through the means of what has been labelled as "social translation."

2. From a practical point of view regarding translation, and just as we had foreseen, although when we are translating multicultural literature, we assume a different social attitude and have the aim of being intercultural mediators, thus bridging social gaps and showing child-readers the differences and similarities between children from all over the world, little does it matter if a scene takes place in a written text from Palestine, Nicaragua, Canada, Africa, Vietnam or where ever, when dealing with or tackling problems which arise in translating multicultural texts. We believe that what counts is that there is a setting or image which has to be carried over to another culture and other readers, and that this has to accomplish a specific purpose: intertextuality. Little does it matter where the languages or cultures have their origins or which target language or culture they are being translated into.

3. Consequently, the strategies we would consider at the time of translating multicultural literature are as follows:

A) Acceptability regarding the target text, paying special attention to both the childreader and the text conventions which this requires.

B) Creativity and intervention on the part of the translator as often as deemed necessary with obtaining acceptability as his or her main objective. 
C) Foreignization, and therefore, respect towards the culture of origin, inter and multiculturalization so as to convey the idea that translation is a remarkable instrument of affinity between children of different cultures.

4. This is our Contemporary Problematic in Translation Studies. Here lies our ambition and our challenge in the future. Through translations of these stories, we will be collaborating in the task of intercultural education, bridging social rifts, breaking down frontiers between different peoples and cultures. Our purpose is that our children are able to learn from the "others" and that they get to know them much better, just as new-comers have to learn our customs and traditions, always reciprocally, so as to attain a true pluralistic and intercultural education.

For intercultural education, it is important to consider why these texts are translated and what the purposes of their translators are. We hope that these multicultural translations, introduced into Spanish schools, provide children with an intercultural understanding. We, as translators, are constructing bridges while dismantling barriers, crossing borders between different peoples and their cultures. Our children will learn more about what the "others" are like and get to know them better.

As someone once quoted, "Literature is the language of the heart." Multicultural literature opens the hearts of the peoples of the world, the hearts of the readers because, remembering Cai's words, it shows not only feelings but perhaps more importantly, the effects of living in a racist society. Voices from the heart can change other hearts. 


\section{WORKS CITED}

Bravo-Villasante, Carmen. Ensayos de literatura infantil. Murcia: Universidad de Murcia, 1989.

CAI, Mingshuni. Multicultural Literature for Children and Young Adults. London: Greenwood, 2002.

Carroll, Lewis. The Nursery Alice. London: Macmillan, 1990.

Hermans, Theo. "Norms and the Determination of Translation: A Theoretical Framework." Translation, Power and Subversion. Ed. R. Álvarez \& C.A. Vidal. Clevedon: Multilingual Matters, 1996.

Hunt, Peter, ed. Children's Literature: The Development of Criticism. London: Routledge, 1990.

KuIngBerg, Gotte. Children's Fiction in the Hands of the Translators. Lund: CWK Gleerup, 1986.

MARÍAS, Javier. Literatura y fantasma. Madrid: Siruela, 1993.

Mollel, Tololowa. Big Boy. New York: Clarion, 1995.

Munsch, Robert. From Far Away. Toronto: Annick, 1995.

Nord, Christiane. “Alice im Niemandsland.” Traducere Navem. Ed. Justa Holz-Mänttäri \& Ch. Nord. Tampere: Tampere Yliopisto, 1993. 395-416.

Oittinen, Riitta. Translating for Children. New York: Garland, 2000.

"Translating for Children and the Media." Actas II Congreso Internacional Traducción, Literatura Infantil y Didáctica. Las Palmas Gran Canaria: ULPGC. Forthcoming.

"Where the Wild Things Are: Translating Picture Books." META 48.1-2. (2003): 128-141.

Pascua Febles, Isabel. La adaptación en la traducción de la literatura infantil. Las Palmas de Gran Canaria: Servicio de Publicaciones ULPGC, 1998.

"Educar en la diferencia: la literatura infantil y juvenil. Proyección social e intercultural. Revista Psicosocial <www.webs.ulpgc.es/revipsicoso> Febrero 2005.

"Inmigración y educación intercultural." La Provincia (Especial Educación). 29 julio 2002, 20.

“La LIJ canadiense: espejo multicultural.” CLIJ 158 (2004): 44-51.

"La literatura infantil como herramienta didáctica para la enseñanza cultural." Actas del VII Congreso Internacional SEDLL. Ed. A. Marco, P. Couto, E. Aradas \& F. Vieito. A Coruña: Diputación Provincial A Coruña, 2004. 507-513.

"El multiculturalismo en la Carta Canadiense de Derechos y Libertades: repercusión en la Europa multiétnica." La Carta Canadiense de Derechos y Libertades bajo perspectivas europeas. Ed. A.R. Celaya, A.Ma Fraile, M.V. Rodríguez \& F. Toda. Salamanca: AEEC, 2003. 347-352. 
_ Los mundos de Alicia de Lewis Carroll: estudio comparativo y traductológico. Las Palmas de Gran Canaria: Servicio de Publicaciones ULPGC, 2000.

"Situación de la literatura para niños en Canadá: su influencia en las traducciones al español." Canadística canaria: ensayos literarios anglocanadienses. Ed. J.I. Oliva, E. Sánchez, L. González \& I. Naranjo. La Laguna: Servicio de Publicaciones Universidad de La Laguna, 2002. 183-196.

"La traducción de la literatura para niños: proyecto educativo intercultural." Traducción y literatura infantil. CD-ROM. Ed. Isabel Pascua. Las Palmas de Gran Canaria: Vicerrectorado de Cultura y Extensión Universitaria y Editorial Anaga, 2003. 25-42.

“Translation and Intercultural Education.” META 48 1-2 (2003): 276-284.

ReISS, Katherina. “Zur Ubersetzung von Kinder und Jugendbüchern.” Lebende Sprachen 27.1 (1982): 7-13.

SÁEnZ, Miguel. "La traducción nueva de una nueva literatura.” Traducción, emigración y culturas. Ed. Hernando de M. Larramendi \& J.P. Arias. Cuenca: Ediciones Universidad Castilla-La Mancha, 1999. 175-178.

SHavit, Zohar. Poetics of Children's Literature. Georgia: U of Georgia P, 1986.

Trottier, Maxine. The Walking Stick. Toronto: Stoddart Kids, 1998.

Valdivielso, Carolina. Literatura para niños: cultura y traducción. Santiago de Chile: Pontificia Universidad Católica de Chile, 1991.

Venuti, Lawrence. The Translator's Invisibility: A History of Translation. London: Routledge, 1995.

VIDAL, C. África. El futuro de la traducción. Valencia: Institució Alfons el Magnànim, 1998. 